ALEKSANDRA JASIELSKA, RENATA A. MAKSYMIUK

$\stackrel{\circ}{\text { II }}$

\title{
DLA KOGO BRAND HERO? O WPŁYWIE BOHATERA MARKI DZIECIĘCEJ NA INTENCJE ZAKUPOWE OSÓB DOROSŁYCH
}

\begin{abstract}
Aleksandra Jasielska, Renata A. Maksymiuk, Dla kogo Brand Hero? O wpływie bohatera marki dziecięcej na intencje zakupowe osób dorosłych [For whom Brand Hero? Influence the children's brand hero on purchasing intentions of adults] edited by A. Jasielska, M. Obrębska ", Człowiek i Społeczeństwo" vol. XLV: Oblicza współczesności. Perspektywa psychologiczna [Faces of modernity. A psychological perspective], Poznań 2018, pp. 169-198, Adam Mickiewicz University. Faculty of Social Sciences Press. ISSN 0239-3271.
\end{abstract}

Brand Hero is a character identifying the brand. It is also the tool of marketing communication especially uses in the case of brands addressed to children. For them, the brand hero is a character with which they create an emotional bond. Therefore is possible, that Brand Hero accompanying product increases its sale, because in the influence market children largely decide about the purchases of goods intended for them. The study was conducted for parents and childless persons $(\mathrm{N}=770)$ and its aim was to identify the influence of 3 types of brad heroes (no-name, multigenerational, mainstream) and lack of brand hero on purchase decisions regarding juice. The outcomes show the participants for themselves chose juice without the hero. When they chose juice for children comparably often chose juice without the hero and with the multigenerational and mainstream hero. The justifications of the choice allowed getting to know the motives that were directed. The most surprising fact was that, for the large group of participants (also parents), the presences of brand hero evoked adverse associations for the brand, and first of all lower quality of the product and manipulation of marketing.

Aleksandra Jasielska, Instytut Psychologii UAM, ul. Szamarzewskiego 89, 60-568 Poznań, e-mail: aleksandra.jasielska@amu.edu.pl

Renata A. Maksymiuk, Instytut Psychologii UMCS, plac Litewski 5, 20-080 Lublin, e-mail:renata.maksymiuk @poczta.umcs.lublin.pl 


\section{Wprowadzenie}

Jednym z określeń opisujących współczesne, postindustrialne, nowoczesne społeczeństwo jest umiarkowanie pobudzający i wartościujący (Riegel i in. 2015) przymiotnik konsumpcyjne (por. Zawadzka, Niesiobędzka i Godlewska-Werner, 2014). W kolokacji ze słowem społeczeństw o zyskuje on na konotacyjnej wyrazistości z tego względu, że to, co jest charakterystyczne dla takiego społeczeństwa, to „komercjalizacja niemal wszystkich aspektów życia. A także - postrzeganie roli konsumenta jako podstawowej roli społecznej” (Iwasiński, 2015, s. 3). W konsekwencji wybrane grupy czy role społeczne ulegają skomercjalizowaniu. Dzieje się tak zarówno w przypadku etapu rozwojowego, jakim jest dzieciństwo (por. komercjalizacja dzieciństwa, Kołodziejczyk, 2012; Schor, 2004; Wilcox i in., 2004), jak i w przypadku symultanicznego względem niego, normatywnego wejścia młodych dorosłych w rolę rodzica (por. skomercjalizowane rodzicielstwo, Halawa, 2006; Jasielska i Maksymiuk, 2011; Solomon, 2004), a zwłaszcza w rolę matki (por. skomercjalizowane macierzyństwo, Lewandowski, 2007; Moskowitz, 2000; Szymańska, 2008).

Zarówno komercjalizacja dzieciństwa, jak i rodzicielstwa są współzmienne z innymi przemianami, jakie można zaobserwować w różnych obszarach społeczno-ekonomicznych, symbolicznie korespondującymi z triadą oddziaływań „soma-psyche-polis” obecnych w przestrzeni psychologicznej człowieka (Brzezińska, 2005, s. 32). Nacisk biologiczny koresponduje ze zjawiskiem „zawiłości wiekowej” (age complexity), przez co segmentacja konsumentów oparta na wieku przestaje być ostateczna i wiarygodna. Nie zawsze bowiem zachowania rynkowe czy wybierane produkty dają się przyporządkować określonej grupie wiekowej (Styś, 2006a). Zawiłość wiekowa idzie w parze z tzw. zjawiskiem KAGOY (Kids Are Getting Older Younger, Schor, 2004, s. 56) oznaczającym, że dzieci są dojrzalsze, niż wskazuje na to ich wiek metrykalny (por. zanikające dzieciństwo, Postman, 1994). Z naciskiem psychicznym koresponduje infantylizacja kulturowa, która polega na tym, że cechy, zachowania i wartości, które były dotąd charakterystyczne dla dzieci, stają się atrybutami osób dorosłych (Bogunia-Borowska, 2006, s. 14; Barber, 2008). Zjawisko to ma dwa oblicza: z jednej strony jest to proces dziecinnienia osób dorosłych, z drugiej - doroślenia dzieci. W związku z tym na przykład przekaz marketingowy kierowany jest do grupy tzw. kidult („dziecinnych dorosłych”, z połączenia angielskich słów kid - dziecko oraz adult - dorosły) oraz poważnych, 
aktywnych na rynku dzieci (Jasielska i Maksymiuk, 2010a). Z naciskami społecznymi koresponduje ekspansywnie rozwijający się zarówno kindermarketing, jak i marketing parentingowy. Kindermarketing (inaczej marketing dziecięcy) obejmuje działania, narzędzia i strategie marketingowe kierowane do dzieci (Jasielska i Maksymiuk, 2010b). Wszystkie one wpisują się w tzw. kidzbiz (Lindstrom, 2005), czyli opracowywanie i wdrażanie przez marki - nie tylko te adresowane bezpośrednio do dzieci - formuły, która konsekwentnie będzie przemawiać do młodych konsumentów. Nie ma bowiem znaczenia, kto jest konsumentem, lecz jaką ma siłę nabywczą (por. marketing od kołyski po grób, cradle-to-grave marketing, Dykalska-Bieck, 2017; Linn, 2004). Z kolei marketing parentingowy (inaczej marketing rodzicielski) kierowany jest do osób dorosłych, które są rodzicami. W jego ramach pozycjonuje się młodych dorosłych w zależności od charakteru związku, liczby posiadanych dzieci, wysokości zarobków itp. (Moskowitz, 2000; Sewera, 2013). Działania marketingowe w tym sektorze podporządkowane są zasadzie sformułowanej przez Charlesa Duhigga (2013, s. 177): „kobiety ciężarne i młodzi rodzice są Świętym Graalem handlu detalicznego. Praktycznie nie istnieje grupa, która umożliwiałaby większe zyski, która byłaby bardziej głodna wszelkich produktów i niewrażliwa na ich cenę”.

W związku z tym, że duża część zakupów dla dzieci dokonywanych jest przez rodziców, ale pod wpływem dzieci (zob. punkt następny), wiele działań marketingowych powstaje na styku kindermarketingu i marketingu parentingowego. Mogą to być np. reklamy kierowane jednocześnie do dziecka i do rodzica sugerujące, że produkt jest atrakcyjny dla obu tych grup, choć dla każdej z nich z innego powodu (Schor, 2005). Przeprowadzone badanie dotyczy podobnej sytuacji. Jego celem było sprawdzenie, czy - a jeśli tak, to w jaki sposób - wykorzystanie Brand Hero, czyli bohatera marki z założenia atrakcyjnego dla dzieci, wpływa na ocenę i deklarację wyboru promowanego w ten sposób produktu.

\section{Dziecko jako konsument, rodzic jako klient}

Kindermarketing odbywa się w obrębie trzech typów rynków (McNeal, 1998). Pierwszy to tzw. rynek pierwotny (primary market), w ramach którego dzieci dokonują wyborów i zakupów samodzielnie. Według firmy GfK (2015) miesięczna siła nabywcza polskich dzieci w wieku szkolnym i wczesnej adolescencji (7-15 lat) wynosiła blisko 348 mln zł. Drugim typem rynku jest tzw. rynek przyszły (future market) zakładający uzyskanie zysków w przyszłości. 
Dzieci jako dorośli same będą dokonywały zakupów, wydając większe sumy. Jeśli od dzieciństwa będą znały określoną markę czy konkretny produkt, to wówczas zdobycie ich lojalności będzie łatwiejsze (McNeal, 1998; por. także Jasielska i Maksymiuk, 2010b). Trzeci to tzw. rynek wpływu (influence market, McNeal, 1998), w ramach którego dzieci wpływają na wybory i decyzje konsumenckie rodziców oraz innych dorosłych członków rodziny. Wpływ ten może mieć dwojaki charakter. Dziecko doradza rodzicom zakup określonego produktu dla nich czy dla rodziny lub nakłania rodziców do zakupu produktu dla siebie (Oczachowska, 2010). W ten sposób pośrednio, poprzez wpływanie na rodziców, dokonuje zakupu (kid-fluence, Schor, 2005). W marketingu sytuacja, w której dziecko prosi osoby dorosłe (nie tylko członków rodziny) o zakup określonego produktu, czy wręcz nalega, używając różnego rodzaju argumentów, identyfikowany jest jako „czynnik marudy” (the nag factor) (Linn, 2004, s. 31; Szlendak, 2005, s. 39) i/lub „siła molestowania” (pester power) (Schor, 2005, s. 61). Marudzenie może przybierać różne formy i eskalować od próśb pod postacią przymilnego nudzenia po ultimatum będące groźbą dozgonnej nienawiści (McNeal, 1998) ${ }^{1}$.

W dyskutowanym obszarze rozróżnia się pojęcie konsumenta i nabywcy (vel klienta). Konsument to osoba, która nie tylko nabywa dobra czy usługi, ale także je spożywa bądź użytkuje (Altkorn i Kramer, 1998). W przypadku rodziców kupujących produkt dla dzieci mówi się zatem nie o konsumencie, ale o nabywcy.

W segmencie produktów przeznaczonych dla dzieci obecne są dwie zasadnicze grupy. Pierwsza z nich to produkty tzw. małego ryzyka, jak słodycze, przekąski, napoje, zabawki, płyty itp., przeznaczone dla dzieci i promowane w sposób dostosowany do tej grupy wiekowej (np. marketing syntoniczny). Druga natomiast to artykuły dla dzieci, takie jak np. produkty do ochrony życia i zdrowia dzieci czy artykuły spożywcze (ale także niektóre zabawki), których promocja adresowana jest do dorosłych. Aby zatem produkt był atrakcyjny zarówno dla dziecka, jak i dla rodzica, coraz częściej pojawiają się przekazy łączące reklamę dla dziecka z reklamą dla rodzica. Dzięki temu zabiegowi producent może odnieść podwójny skutek: zainteresować dziecko i przekazać racjonalne argumenty rodzicom. Zdaniem marketerów reklamy, które starają się łączyć oba te cele, są coraz bardziej skuteczne (Całka, 2006).

${ }^{1}$ „Czynnik marudy” nie zostanie dokładnie omówiony w niniejszym artykule. Czytelnika zainteresowanego tą problematyką odsyłamy do licznych publikacji na ten temat (Comstock i Scharrer, 2007; Gunter i Furnham, 1998; Jasielska i Maksymiuk, 2010b; Jasielska i Maksymiuk, 2011; Linn, 2004). 
Pozycjonowanie produktów dla dzieci wykorzystuje z jednej strony strategie skrojone dla dorosłych konsumentów przeniesione na grunt kindermarketingu, z drugiej nawiązuje do dziecięcej percepcji świata, stąd obecność w produktach dla dzieci bohatera marki, z języka angielskiego - Brand Hero.

\section{Brand Hero}

Marka to kombinacja nazwy, symbolu, znaku graficznego, koloru i innych atrybutów, charakterystyczna dla danego produktu i mająca na celu odróżnienie go od produktów konkurencji. Marka jest również niekiedy utożsamiana z samym produktem (Altkorn i Kramer, 1998). Jednym z narzędzi komunikacyjnych jest Brand Hero. Jest to postać towarzysząca marce czy z marką utożsamiana, inaczej personifikacja marki. Bohater marki jest czymś więcej niż tylko składnikiem logo czy elementem towarzyszącym logotypowi (Styś, 2006b). Jest swoistym uosobieniem, które dzięki swoim charakterystycznym formie i cechom nawiązuje komunikację z konsumentem.

Funkcje. Bohater marki jest jednym z elementów tożsamości firmy, który aranżuje komunikację z klientem. Celem wprowadzania bohatera marki jest wyróżnienie jej na rynku, wpływ na jej zapamiętanie i zbudowanie więzi z klientem. Podstawową funkcją Brand Hero jest przyciąganie uwagi konsumenta, co ułatwia wyróżnienie się na tle produktów konkurencyjnych. Ponadto bohater ma wzbudzać sympatię, aby konsument przypisał jego pozytywne cechy danej marce. Postać ma również intrygować, wzbudzać zainteresowanie, tak aby chciało się z nią pozostać na dłużej. Kolejną i jednocześnie jedną z ważniejszych funkcji jest komunikacja, która polega na przekazywaniu i odbieraniu informacji między producentem a rynkiem. Bohater dzięki posiadanym cechom komunikuje się z konsumentem i pozwala mu poznać i zrozumieć markę. Ponadto Brand Hero buduje lojalności wobec marki (Dołhasz, 2013). Jest to funkcja nadrzędna wobec pozostałych, gdyż właśnie dzięki budzeniu sympatii, komunikowaniu się z konsumentem i intrygowaniu buduje więź między sobą, marką, a konsumentem. Dodatkowo, jeśli bohater marki występuje zarówno w reklamie, jak i na opakowaniu produktu, to działa jak wskazówka przywoływania (retrieval cue) treści reklam. Innymi słowy, stykając się w sklepie z postacią znaną z reklamy, klient przypomina sobie obiecywane w tej reklamie korzyści z użytkowania danego produktu czy marki (por. Stasiuk i Maison, 2014).

Cechy. Istnieje zbiór cech, które bohater marki powinien posiadać. Po pierwsze, powinien opierać się na przeciwieństwach. Kontrast cech 
bohatera wywołuje budzące zainteresowanie napięcie, a ponadto „mocne i ważne kulturowo opozycje są przydatne w tworzeniu Brand Heroes, ponieważ są powszechnie zrozumiałe, uzasadnione kulturowo i historycznie" (Rudnicki i Szwed, 2014). Brand Hero powinien być jak najbardziej antropomorficzny, czyli posiadać jak najwięcej cech ludzkich. Postać o takim charakterze jest bardziej atrakcyjna dla odbiorców, gdyż ułatwia identyfikowanie i sympatyzowanie z nią. Ważne jest także, aby bohater był odrobinę przerysowany, unikatowy i wyrazisty zarówno pod względem wyglądu, jak i cech charakteru (Dołhasz, 2013). Bohater marki powinien także wykorzystywać efekt substytucji (Kahneman, 2012), czyli zastępować abstrakcyjny czy trudny do zrozumienia przekaz łatwiejszym i bardziej przystępnym, takim, który pozwala na szybkie ocenienie wad i zalet. Dzięki temu może funkcjonować jako tłumacz czy metafora wartości marki. Istotne jest także, aby Brand Hero korelował z tzw. archetypem marki, który opisuje daną firmę. Może „być przedłużeniem” archetypu marki, całkowicie się w niego wpisywać, być niejako rzecznikiem wartości i cech marki lub przeciwnie postawić się w kontraście do archetypu marki (Mark i Pearson, 2001).

Rodzaje. Jednym z najbardziej znanych Brand Hero jest wykreowany dla firmy Michelin ludzik Bibendum, który od roku 1894 reprezentuje tę markę opon. Z kolei od roku 1963 znany jest Ronald McDonald, klaun kojarzony z siecią fast foodów McDonald’s. Postać ma charakterystyczny wygląd i strój w kolorach firmowych. Według Wikipedii 96\% dzieci w wieku szkolnym prawidłowo skojarzyła postać z firmą. Od roku 1971 Brand Hero firmy Duracell, producenta baterii, jest różowy króliczek napędzany baterią Duracell przytwierdzoną do pleców. Z kolei od roku 1972 produktom firmy Milka towarzyszy fioletowa krowa. Już ten pobieżny przegląd pokazuje, że rodzaje Brand Hero mogą być bardzo różne, choć w większości bohaterami marek - w szczególności dziecięcych - bywają postaci zwierząt (Styś, 2006b; por. Szubielska i Dziopa, 2017). Dzieje się tak, ponieważ pozytywne konotacje emocjonalne przypisywane zwierzętom są bardzo silne, jednoznaczne i mają uniwersalny charakter. W badaniach Chodorowskiej (2013) okazało się, że spośród kilkunastu postaci zwierząt badani preferowali trzy o najsilniejszym ładunku cech pozytywnych: lwa, lisa i sowę. Seria badań pokazała, że maskotka przekaże swoje cechy produktowi, jeśli jej charakter odpowiada marce, a klienci przyzwyczajeni są do tego typu komunikatu. Jeśli jednak postać nie pasuje do produktu, efekt może być odwrotny do zamierzonego.

W tabeli 1 przedstawiono typologię Brand Hero i ich przykłady obecne w produktach dedykowanych zarówno dorosłym, jak i dzieciom. 
Tabela 1. Typologia Brand Hero

\begin{tabular}{|c|c|c|c|}
\hline \multirow{2}{*}{ Typ } & \multirow{2}{*}{ Opis } & \multicolumn{2}{|c|}{ Przykłady Brand Hero } \\
\hline & & \begin{tabular}{|c|} 
Dorośli \\
\end{tabular} & \begin{tabular}{|r|} 
Dzieci \\
\end{tabular} \\
\hline $\begin{array}{l}\text { Rzeczywista } \\
\text { osoba związana } \\
\text { z marką przez } \\
\text { długi czas }\end{array}$ & $\begin{array}{l}\text { osoba popularna, rozpozna- } \\
\text { walna, która jest sobą; może } \\
\text { to być aktor, celebryta lub } \\
\text { bohater zbiorowy }\end{array}$ & $\begin{array}{l}\text { Marek Kondrat - } \\
\text { ING Bank Śląski } \\
\text { (usługi bankowe) }\end{array}$ & $\begin{array}{l}\text { youtuberzy - } \\
\text { zabawka Nerf }\end{array}$ \\
\hline $\begin{array}{l}\text { Bohater } \\
\text { uosabiający } \\
\text { nazwę marki }\end{array}$ & $\begin{array}{l}\text { postać rzeczywista lub ani- } \\
\text { mowana będąca uosobieniem } \\
\text { nazwy marki }\end{array}$ & $\begin{array}{l}\text { postać Harnasia - } \\
\text { Harnaś (piwo) }\end{array}$ & $\begin{array}{l}\text { postać niedźwiadka - } \\
\text { Kubuś (sok, woda) }\end{array}$ \\
\hline $\begin{array}{l}\text { Bohater jako } \\
\text { ożywiony } \\
\text { produkt }\end{array}$ & $\begin{array}{l}\text { zaanimowany, obdarzony ce- } \\
\text { chami i atrybutami ludzkimi, } \\
\text { zhumanizowany produkt }\end{array}$ & \begin{tabular}{|l} 
Delmik, kawałek \\
margaryny - \\
Delma (margaryna)
\end{tabular} & $\begin{array}{l}\text { Milky, Lilly i Billy } \\
\text { (Pastusie): fragmenty } \\
\text { pasty do zębów, } \\
\text { najbliżsi przyjaciele } \\
\text { Kapitana Aquafresh } \\
\text { (pasta do zębów) }\end{array}$ \\
\hline \multirow[t]{2}{*}{ Postać fikcyjna } & $\begin{array}{l}\text { stworzona dla potrzeb marki } \\
\text { (kreskówkowa, animizowa- } \\
\text { na, animowana) postać (lub } \\
\text { postacie, których kreacja czę- } \\
\text { sto opiera się na antynomii) }\end{array}$ & $\begin{array}{l}\text { podobna do rzeczy- } \\
\text { wistej: } \\
\text { Henio i Krysia - } \\
\text { Tesco (sieć hiper- } \\
\text { i supermarketów) } \\
\end{array}$ & $\begin{array}{l}\text { podobna } \\
\text { do rzeczywistej: } \\
\text { superbohater - } \\
\text { Picollo (szampan } \\
\text { bezalkoholowy) } \\
\end{array}$ \\
\hline & $\begin{array}{l}\text { podobna do rzeczywistej lub } \\
\text { wymyślona }\end{array}$ & \begin{tabular}{|l|} 
wymyślona: \\
Pan Pikuś - Aviva \\
(usługi ubezpiecze- \\
niowo-finansowe) \\
\end{tabular} & $\begin{array}{l}\text { wymyślona: } \\
\text { Plemię Melitków - } \\
\text { Melitki (witamina } \\
\text { D do ssania) }\end{array}$ \\
\hline $\begin{array}{l}\text { Postać fikcyjna } \\
\text { grana przez } \\
\text { aktora }\end{array}$ & $\begin{array}{l}\text { aktorzy lub naturszczycy } \\
\text { wcielający się w postacie } \\
\text { związane z marką (często } \\
\text { w parach) }\end{array}$ & $\begin{array}{l}\text { Blondynka i Brunet - } \\
\text { Play (sieć telefonii } \\
\text { komórkowej) }\end{array}$ & $\begin{array}{l}\text { wizerunek dziecka - } \\
\text { Kinder Chocolate } \\
\text { (batoniki czekola- } \\
\text { dowe) }\end{array}$ \\
\hline Antybohater & $\begin{array}{l}\text { bohater stanowiący opozycję } \\
\text { wobec produktu, wywołujący } \\
\text { swym wizerunkiem negatyw- } \\
\text { ne skojarzanie }\end{array}$ & \multicolumn{2}{|c|}{ Mały Głód - Danio (serek homogenizowany) } \\
\hline Idea bohatera & $\begin{array}{l}\text { bohater przekazujący symbo- } \\
\text { liczne wartości danej marki }\end{array}$ & $\begin{array}{l}\text { Serce i Rozum (Tele- } \\
\text { komunikacja Polska) } \\
\text { Ocieplenie wizerunku } \\
\text { monopolisty dzięki } \\
\text { ludzkim atrybutom - } \\
\text { uczuciom i myśleniu }\end{array}$ & \begin{tabular}{|l|} 
fioletowa krowa \\
Milka (produkty \\
czekoladowe) pro- \\
mowanie czułości \\
i delikatności \\
w relacjach inter- \\
personalnych \\
\end{tabular} \\
\hline $\begin{array}{l}\text { Tajemnicza } \\
\text { postać } \\
\text { niewystępująca } \\
\text { w reklamie }\end{array}$ & $\begin{array}{l}\text { wykreowany niewidoczny } \\
\text { bohater marki, którego wize- } \\
\text { runek tworzy się w umyśle } \\
\text { klienta }\end{array}$ & $\begin{array}{l}\text { Goździkowa - } \\
\text { etopiryna } \\
\text { (lek przeciwbólowy) }\end{array}$ & brak \\
\hline
\end{tabular}

Źródło: opracowanie własne na podstawie Müller, 2016; Styś, 2006b. 
W powyższym zestawieniu na szczególną uwagę zasługują dwie ostatnie kategorie bohatera, które w niewielkim zakresie mogą być stosowane w produktach dla dzieci z tego powodu, że bazują na przekazie abstrakcyjnym. Dziecko ze względu na swoje ograniczenia w rozwoju poznawczym nie jest gotowe interpretować danych, które nie są konkretne (Trempała, 2002). Badania socjologiczne przeprowadzone w Niemczech pokazały, że pod wpływem reklamy czekolady Milka połowa badanych dzieci wierzyła, że krowy mają kolor fioletowy (Rotkiewicz, 1995). Wiąże się to z faktem, że dokonywanie operacji umysłowych na przedmiotach lub zdarzeniach, które mogą być wymyślone, jest możliwe dopiero po 12. roku życia (Trempała, 2002).

\section{Brand Hero dziecięcych marek}

Choć przytoczone powyżej dane pokazują, że bohater marki funkcjonuje w komunikacji marketingowej z osobami w każdym wieku, to w zasadzie wszystkie produkty kierowane do dzieci, niezależnie od kategorii, funkcjonują na rynku lepiej, jeżeli mają przypisaną jakąś postać, dzięki której są właściwie identyfikowane. Dla dzieci w wieku przedszkolnym czy wczesnoszkolnym bohater marki często po prostu jest marką. Dzieci, które jeszcze nie czytają, nie posługują się logotypem ani nazwą, posługują się pewną postacią.

Istnienie bohatera marki koresponduje ze zjawiskami normatywnymi w rozwoju dziecka. Wiadomo bowiem, że dzieci lubią: bajki, komedie, rozpoznawalne postacie, proste fabuły, przedstawienia o charakterze kiczu oraz koncentrują uwagę na przekazach dynamicznych (Maison, 1998; Godlewska i Gorbaniuk, 2007; Podlaszewska i Szlendak, 2003). Ponadto dzieci preferują humor słowny i sytuacyjny, pozytywne emocje, atmosferę zabawy i rozrywki. Cechą charakterystyczną rozwoju poznawczego dzieci w wieku 2-7 lat jest myślenie animistyczne, czyli przekonanie, że każdy przedmiot jest żywy, myśli i czuje (Piaget, 2006, s. 137).

W przypadku dzieci bohater czy maskotka marki są traktowane jako rodzaj zabawki lub wizerunku zabawki. Zabawka z kolei, która stanowi ważny element dziecięcego środowiska, jest niezbędnym atrybutem zabawy stanowiącej naturalną i dominującą formę aktywności w okresie dzieciństwa. W aspekcie rozwojowym zabawka może służyć jako symbol czy reprezentacja realnego obiektu, może dziecko pocieszać bądź pomagać mu rozładowywać stres, zachęcać do aktywności fizycznej, rozwijać sprawność manualną oraz służyć do nawiązywania i podtrzymywania więzi 
rówieśniczej (Sutterby, 2009). W wieku przedszkolnym następuje gwałtowny rozwój funkcji symbolicznej, czego wyrazem jest m.in. zabawa symboliczna (w szczególności jej II stadium w terminologii Piageta (2006)). Dziecko częściowo odrywa się od konkretnych przedmiotów i nadaje przedmiotom używanym w zabawie oraz zabawkom zastępcze znaczenie (np. używanie ołówka jako termometru, krzesła jako samochodu).

Podobnie jak w przypadku osób dorosłych, także bohater marki dziecięcej może być kreowany przez różnorodne postacie (por. Szol, 1979). $\mathrm{Z}$ jednej strony mogą to być osoby realne, z drugiej zaś może to być bohater popularnego wśród dzieci filmu czy gry komputerowej lub postać stworzona na potrzeby danego produktu. Dobrym sposobem jest tworzenie bohaterów, którzy żyją w serii reklam, a te są opowieścią o jego przygodach związanych z marką czy produktem. Obecny w reklamie bohater mówi o produkcie, a jego przygody są pretekstem do pokazywania produktu i jego atrybutów (Pallach, 2013). Przejście od bohatera bajki do bohatera marki, a następnie reklamy, która często realizuje konwencję baśniową, jest dość płynne (van Buuren, 2017). „Gdy dziecko pokocha bohatera marki (tak jak jest w stanie pokochać postać bajkową), to zechce mieć swojego ulubieńca na plakacie, piórniku, tornistrze...” (Styś, 2006b, s. 50).

Analogicznie jak w przypadku dorosłych marek, bohaterowie marek dziecięcych mogą nawiązywać do archetypów firmy, np. archetypu Duszy Towarzystwa z mottem „Śmiech jest najlepszym lekarstwem” i zaanimowanej drażetki M\&M’s „Leci w kulki” czy archetypu Twórcy, w ramach którego „Wyobraźnia to możliwość”, a figurka Lego „Inspiruje i rozwija budowniczych jutra” (Mark i Pearson, 2001). Możliwe kategorie bohaterów dziecięcych marek przedstawia tabela 2.

Tabela 2. Rodzaje bohaterów dziecięcych marek

\begin{tabular}{|l|l|l|}
\hline \multicolumn{1}{|c|}{ Bohater } & \multicolumn{1}{|c|}{ Opis } & \multicolumn{1}{c|}{ Przykład } \\
\hline Długofalowy & $\begin{array}{l}\text { pozytywny bohater, stworzony na potrzeby } \\
\text { marki, który razem z nią ewoluuje, przy } \\
\text { czym zmiany wizerunku bohatera są pra- } \\
\text { wie niedostrzegane przez rodziców i dzieci }\end{array}$ & $\begin{array}{l}\text { miś Kubuś, } \\
\text { smok Pysio }\end{array}$ \\
\hline Licencjonowany & $\begin{array}{l}\text { postać znana i atrakcyjna dla dzieci, po- } \\
\text { chodząca z książek, filmów lub gier kom- } \\
\text { puterowych, często obca rodzicom }\end{array}$ & $\begin{array}{l}\text { Angry Birds, } \\
\text { Harry Potter, } \\
\text { Monster High }\end{array}$ \\
\hline $\begin{array}{l}\text { Chwilowy/ } \\
\text { mainstreamowy }\end{array}$ & $\begin{array}{l}\text { postać związana z aktualnymi hitami kina } \\
\text { dziecięcego i czasowo wykorzystywana } \\
\text { do promocji w trakcie trwania mody na } \\
\text { dany film }\end{array}$ & $\begin{array}{l}\text { Minionek - } \\
\text { „Minionki”, } \\
\text { superbohaterowie - } \\
\text { „Iniemamocni 2” }\end{array}$ \\
\hline
\end{tabular}


cd. tab. 2

\begin{tabular}{|l|l|l|}
\hline \multicolumn{1}{|c|}{ Bohater } & \multicolumn{1}{|c|}{ Opis } & \multicolumn{1}{c|}{ Przykład } \\
\hline $\begin{array}{l}\text { Wspólny/wielo- } \\
\text { pokoleniowy }\end{array}$ & $\begin{array}{l}\text { uniwersalni bohaterowie wielopokolenio- } \\
\text { wi, rozpoznawani przez dziadków, rodzi- } \\
\text { ców i dzieci, często licencjonowani }\end{array}$ & $\begin{array}{l}\text { Kubuś Puchatek, } \\
\text { Garfield }\end{array}$ \\
\hline Dziecięcy & $\begin{array}{l}\text { postać znana, ale niebudząca sympatii } \\
\text { u rodzica lub postać niszowa, nieznana } \\
\text { rodzicom }\end{array}$ & Sims, Ben 10 \\
\hline $\begin{array}{l}\text { Rodziców/ } \\
\text { oldschoolowy }\end{array}$ & $\begin{array}{l}\text { postać pochodząca z dzieciństwa rodzi- } \\
\text { ców, nieznana dzieciom, mało lub prawie } \\
\text { wcale dla nich nie atrakcyjna, o której } \\
\text { rodzice muszą dzieciom opowiadać lub } \\
\text { zadbać o to, by dziecko miało możliwość } \\
\text { „zapoznać” się z postacią }\end{array}$ & Kot Filemon \\
\hline $\begin{array}{l}\text { Wschodzący/ } \\
\text { no-name }\end{array}$ & $\begin{array}{l}\text { bohater wchodzący na rynek stworzo- } \\
\text { ny dla potrzeb pozycjonowania marki } \\
\text { jako dziecięcej zgodnie z zasadami } \\
\text { kreacji marki i egzekucji kreatywnej }\end{array}$ & \\
\hline
\end{tabular}

Źródło: opracowanie własne na podstawie Frąckiewicz, 2007; Jędrkiewicz, 2006; por. Jasielska i Maksymiuk, 2010b, s. 81.

Ostatnia w powyższej tabeli kategoria Brand Hero dotyczy bohatera nowego, nieznanego z innych przekazów kierowanych do dzieci (tj. bajek, filmów, książek, gier itp.), „debiutującego” na rynku. Tworzenie takiego bohatera marki „od podstaw” ma swoje zalety i wady. Do zalet można zaliczyć fakt, że postać ta może być w pełni dostosowana do komunikacji marki. Z kolei ryzyko wprowadzenia takiej postaci wiąże się z faktem, że w początkowym okresie bohater ten jest postacią niejako obcą, pozbawioną historii. Nie wywołuje żadnych skojarzeń ani nie wzbudza pozytywnych emocji - choćby wynikających z efektu samej ekspozycji (Zajonc, 1985) przez co istnieje możliwość, że nie zostanie zaaprobowany. Zanim więc stanie się rozpoznawany, akceptowany i identyfikowany z marką, jest pewnego rodzaju postacią no-name i musi zostać odpowiednio wypromowany (Witek-Hajduk, 2010).

Istnienie bohatera marki jest atrakcyjne dla dzieci, ale także istotne z punktu widzenia rodziców. Po pierwsze, rodzice wiedzą, że produkt jest przeznaczony dla dziecka, po drugie, mogą wnioskować na tej podstawie o jakości, składzie itp., czasem zupełnie nie mając po temu racjonalnych przesłanek. Wyniki badań pokazują, że rodzice chętniej sięgną po produkt, na którym widnieje postać, niż po taki, na którym postaci nie ma (Jędrkiewicz, 2006). 
Biorąc pod uwagę różnorodność bohaterów dziecięcych marek, można postawić pytanie, który z nich najlepiej wypełni swoje funkcje i w efekcie skłoni rodzica do zakupu produktu dla dziecka. Można bowiem założyć, że jeśli rodzice kierują się preferencjami swoich dzieci, kupując przeznaczone dla nich produkty (rynek wpływu), to zapewne chętniej wybiorą produkt z bohaterem marki niż bez bohatera. Z kolei bohater znany dziecku z bajek czy filmów, niosący za sobą szereg pozytywnych skojarzeń - a przede wszystkim pozytywnych emocji - będzie zapewne bardziej atrakcyjny niż postać nowa, nieznana, o nieokreślonej tożsamości. Można także uznać, że kupując ten sam produkt dla dziecka oraz dla siebie, rodzice kierują się innymi motywami, dlatego bohater dziecięcej marki może skłonić do zakupu produktu dla dziecka, ale nie dla siebie. Jeśli zaś chodzi o osoby dorosłe, to można założyć, że bohaterowie dziecięcych marek nie będą dla nich atrakcyjni na tyle, by skłonić ich do zakupu produktu, ponieważ więź emocjonalna z bohaterem nie jest już tak silna jak w okresie dzieciństwa. Powyższe rozważania sprawdzono empirycznie, przeprowadzając badanie, które miało na celu zweryfikowanie następujących hipotez:

H1: Uczestnicy badania częściej będą wybierali dla siebie sok bez bohatera niż z bohaterem marki dziecięcej, także wówczas gdy są rodzicami.

H2: Uczestnicy badania będą częściej wybierali dla dzieci sok z bohaterem marki dziecięcej niż bez bohatera.

H3: Uczestnicy badania będą częściej wybierali dla dzieci sok z bohaterem mainstreamowym oraz wielopokoleniowym niż bohaterem no-name.

H4: Motywy wyboru soku dla siebie będą różniły się od motywów wyboru soku dla dziecka.

\section{Metoda i procedura}

W przeprowadzonym eksperymencie osoby badane miały za zadanie wybrać jedną z czterech wersji soku owocowego dla siebie (osoby bezdzietne i rodzice) oraz dla dziecka (tylko rodzice), a następnie uzasadnić swoją decyzję (pytanie otwarte).

W badaniu pilotażowym $(\mathrm{N}=10)$ sprawdzono przygotowaną procedurę, a następnie przeprowadzono badanie właściwe. 


\section{Osoby badane}

Uczestników badania ( $\mathrm{N}$ = 1177) zrekrutowano za pośrednictwem jednego z portali społecznościowych, gdzie w grupach tematycznych umieszczono posty z prośbą o wypełnienie ankiety². Udział był dobrowolny i bezpłatny. Ze względów proceduralnych (braki danych, wiek dziecka) do analiz statystycznych zakwalifikowano 770 osób, w tym 661 kobiet (87\%) i 99 mężczyzn (13\%), w wieku od 20 do 48 lat $(\mathrm{M}=27$, DS = 5,71).

W badanej grupie 452 osoby (59\%) nie miały dzieci, a 318 (41\%) było rodzicami przynajmniej jednego dziecka w wieku od roku do dziesięciu lat. Byli to mieszkańcy wsi - 14\%, małych miast (do 20 tys. mieszkańców) $13 \%$, średnich miast (od 20 tys. do 100 tys. mieszkańców) - 21\% oraz dużych miast i ośrodków wielkomiejskich (powyżej 100 tys. mieszkańców) - 52\%. Wykształcenie podstawowe, zawodowe lub gimnazjalne miało 7\% osób, średnie $47 \%$, a wyższe $46 \%$. Zdecydowana większość (87\%) osób zadeklarowała, że jest odpowiedzialna za zakupy spożywcze dla domu. Zdecydowana większość rodziców zadeklarowała, że dziecko/dzieci towarzyszy/ą im podczas robienia zakupów spożywczych (80\%), a jeszcze większa grupa stwierdziła, że w swoich decyzjach zakupowych uwzględnia preferencje dziecka/dzieci.

\section{Zmienne}

Zmienna niezależna: wpływ wizerunku bohatera marki (Brand Hero) na decyzje zakupowe. Zmienna miała cztery poziomy: (1) brak bohatera marki na etykiecie soku (jedynie rysunek owocu); (2) bohater no-name (Małpka stworzona na potrzeby badania widoczna na tle rysunku owocu); (3) bohater wielopokoleniowy (Kłapouchy z bajki o Kubusiu Puchatku widoczny na tle rysunku owocu) oraz bohater mainstreamowy (pingwin z bajki „Pingwiny z Madagaskaru” widoczny na tle rysunku owocu).

Zmienna zależna: decyzja o wyborze produktu (1) dla siebie oraz (2) dla dziecka (w przypadku rodziców).

Zmienna wyjaśniająca: pytania sprawdzające, czy rodzice kierują się preferencjami dziecka w swoich decyzjach zakupowych oraz czy dziecko towarzyszy rodzicom podczas zakupów.

${ }^{2}$ Badanie przeprowadzone zostało przez Agatę Domską (2016) w ramach seminarium magisterskiego prowadzonego przez dr hab. Aleksandrę Jasielską. 


\section{Materiał badawczy}

Na potrzeby badania stworzono cztery grafiki przygotowane zgodnie z zasadami egzekucji graficzno-kreatywnej, przedstawiające szklaną butelkę soku owocowego typu twist-off o pojemności $330 \mathrm{ml}$. Butelka była przezroczysta i widać było w niej sok koloru pomarańczowego. Etykieta miała przezroczyste tło, dzięki czemu na tle soku widoczna była grafika: „owoc” składający się z pokrojonych, poukładanych na sobie plastrów różnych owoców (jabłka, pomarańczy, cytryny itp.) oraz umieszczony nad nim napis „Organic juice 100\%”. W zależności od warunku badania na trzech wersjach przed owocem znajdował się jeden z bohaterów marki (no-name, wielopokoleniowy lub mainstreamowy) (zob. rycina poglądowa 1).
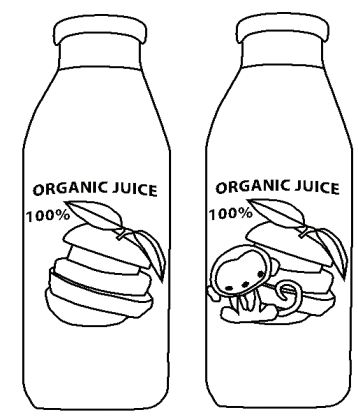

Rycina 1. Wybrane matryce soków użytych w badaniu Źródło: opracowanie własne.

\section{Procedura badania}

Uczestnicy badania otrzymywali link do ankiety internetowej. Po uzupełnieniu danych socjodemograficznych respondenci przechodzili do właściwej części badania. Ich zadaniem było zapoznanie się z czterema wersjami soku różniącymi się etykietą i wskazanie, którą z wersji wybraliby dla siebie oraz dla dziecka (tylko rodzice). Chcąc uniknąć wpływu kolejności prezentowanych grafik na decyzję badanych, wyświetlano je w kolejności losowej dla każdej osoby. Następnie badanych proszono o wpisanie uzasadnienia decyzji. Dodatkowo rodzice biorący udział w badaniu udzielali odpowiedzi na pytanie, czy uwzględniają w swoich decyzjach zakupowych preferencje dzieci oraz czy dzieci towarzyszą im podczas robienia zakupów spożywczych dla rodziny. 


\section{Wyniki}

\section{Analiza ilościowa - wybór soku dla siebie}

W pierwszej kolejności sprawdzono, którą wersję soku uczestnicy badania wybrali dla siebie. Najwięcej osób wybrało wersję bez bohatera (wykres 1).

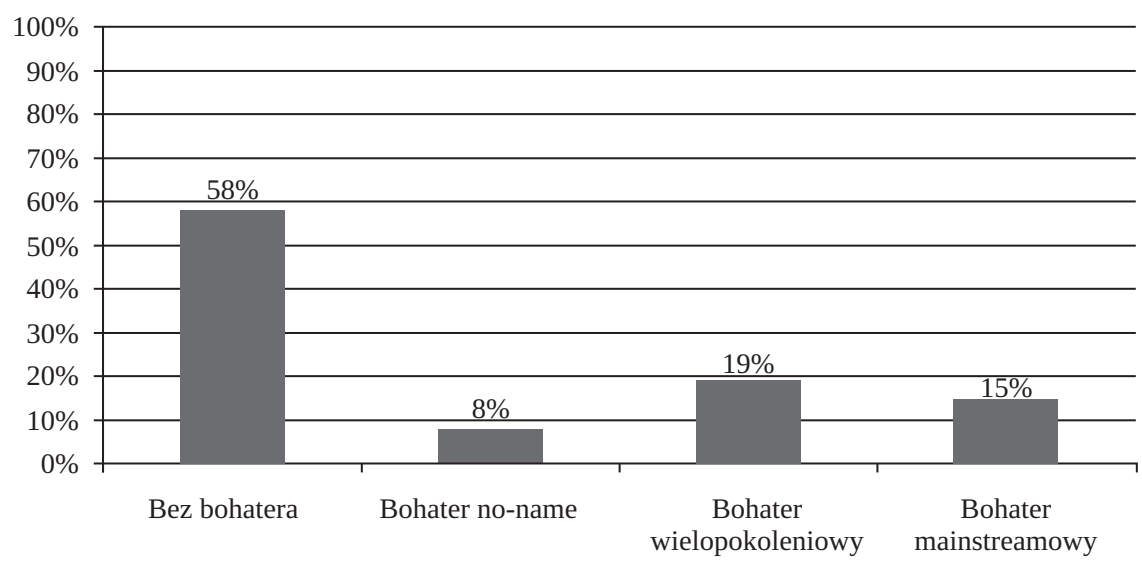

Wykres 1. Procentowy rozkład wyborów soku dla siebie

Źródło: opracowanie własne.

W kolejnym kroku uczestników badania podzielono na dwie grupy: (1) osoby, które wybrały sok bez bohatera marki, i (2) osoby, które wybrały sok z bohaterem marki. Analiza statystyczna testem $\mathrm{chi}^{2}$ wykazała, że istotnie więcej osób wybrało wersję bez bohatera (58\%) niż z bohaterem marki $\left(32 \%, X_{(1, N=770)}^{2}=20,62 ; \mathrm{p}<.001\right)$.

Następnie przeprowadzono analizy oddzielnie dla osób bezdzietnych oraz rodziców. Zarówno rodzice, jak i osoby bezdzietne częściej wybierali sok bez bohatera marki (odpowiednio 60\% i 57\%) niż z bohaterem (odpowiednio 40\% i 43\%), w obu grupach różnice były istotne statystycznie (dla rodziców $\chi^{2}{ }_{(1, \mathrm{~N}=318)}=13,7 ; \mathrm{p}<.001$, a dla osób bezdzietnych $\left.X_{(1, \mathrm{~N}=452)}^{2}=7,96 ; \mathrm{p}<.01\right)$, nie zanotowano jednak różnic istotnych statystycznie w wyborze wersji bez bohatera między rodzicami i osobami bezdzietnymi $\left(\chi_{(1, \mathrm{~N}=448)}^{2}=0,64\right.$; n.i.).

Jeśli chodzi o wersję soku z bohaterem marki, to najczęściej wybierano bohatera wielopokoleniowego, a najrzadziej - no-name (wykres 2). W żadnej z wersji nie zanotowano różnic istotnych statystycznie między rodzicami a osobami bezdzietnymi. 


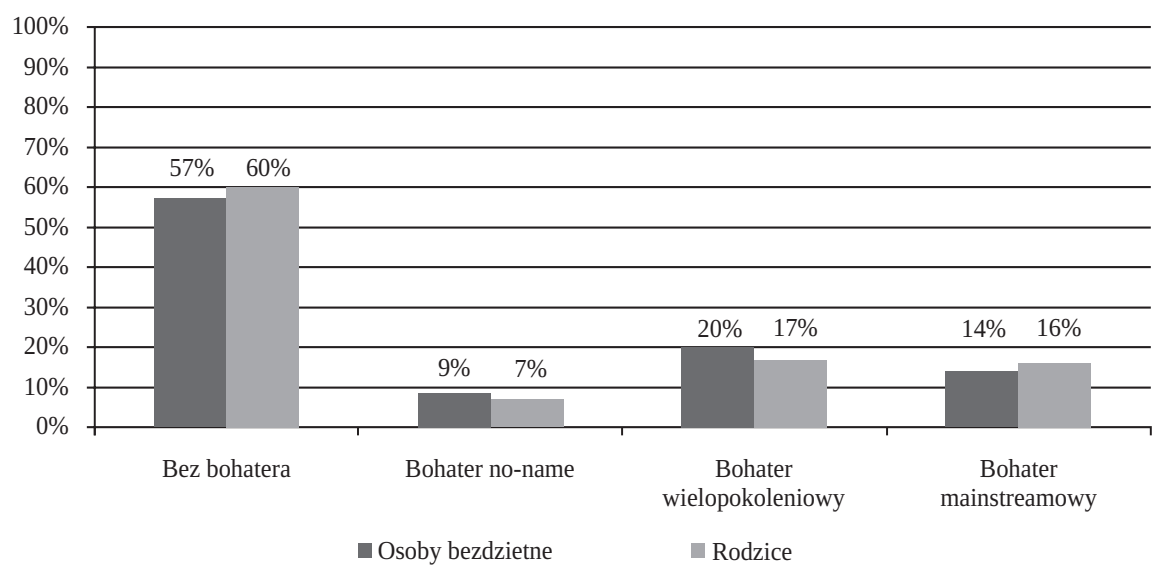

Wykres 2. Procentowy rozkład wyborów soku dla siebie

z podziałem na osoby bezdzietne i rodziców

Źródło: opracowanie własne.

\section{Analiza ilościowa - wybór soku dla dziecka}

W pierwszej kolejności sprawdzono, którą z wersji soku rodzice wybrali dla swojego dziecka. Analiza statystyczna testem chi ${ }^{2}$ wykazała, że różnice w częstościach wyboru były istotne statystycznie $\left(\mathrm{X}_{(3, \mathrm{~N}=318)}^{2}=29,19 ; \mathrm{p}<.001\right)$. Najmniej osób preferowało wersję z bohaterem no-name (wykres 3 ).

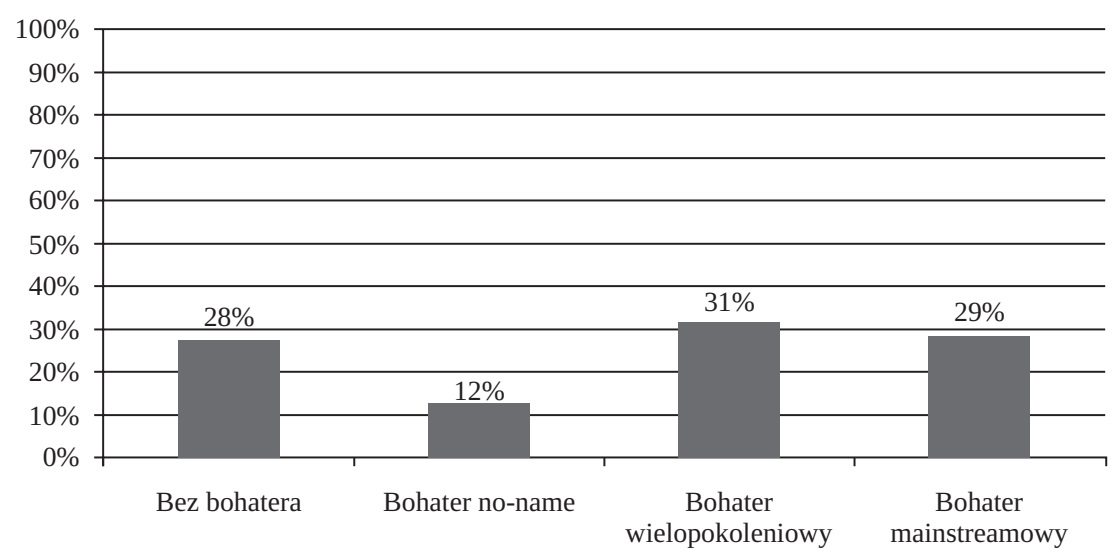

Wykres 3. Procentowy rozkład wyborów soku dla dziecka Źródło: opracowanie własne.

Następna analiza testem $\operatorname{chi}^{2}\left(\mathrm{X}_{(2, \mathrm{~N}=228)}^{2}=28,60 ; \mathrm{p}<.001\right)$ wykazała, że także wśród rodziców wybierających jedną z trzech wersji soku z bohaterem marki najmniejszą popularnością cieszył się bohater no-name (17\%). 
Bohatera wielopokoleniowego i mainstreamowego wybierano z podobną częstością (odpowiednio 42\% i 41\%).

\section{Analiza jakościowa - uzasadnienie wyboru soku}

Uzasadniając wybór określonej wersji soku, badani odpowiadali na otwarte pytanie „Dlaczego wybrał(a) Pan(i) ten sok?”. Jakościowa analiza uzyskanych informacji wykazała, że część motywów wyboru była wspólna zarówno w sytuacji, gdy wybierano sok dla siebie, jak i dla dziecka, a także zarówno przez rodziców, jak i osoby bezdzietne. Należały do nich: (1) zdrowie, (2) świadomość konsumencka, (3) ekonomia, (4) prostota oraz (5) sympatia do bohatera.

\section{- Zdrowie}

Motyw zdrowia najczęściej wymieniany był przez osoby, które wybrały wersję bez bohatera marki. Uznały one, że etykieta z samym owocem wzbudzała większe zaufanie. Produkt wydaje się bardziej naturalny, ma „lepszy skład”, nie jest dosładzany ani „wzbogacany” dodatkowymi środkami chemicznymi. Duża część twierdziła, że obecność bohatera marki sugeruje przeznaczenie tego soku dla dzieci, a to z kolei wiąże się, ich zdaniem, z „dostosowaniem” do dziecięcych preferencji - dodaniem cukru lub słodzików, sztucznych aromatów i barwników.

Inne etykiety kojarzyły mi się z dziećmi, a większość soków dla dzieci zawiera dużo chemii.

Grafiki na sokach zazwyczaj kojarzą mi się z sokami dla dzieci i większość soczków niestety ma dużo niezdrowych substancji...

Soki organiczne z dziecięcą naklejką mogą świadczyć o zawartości cukru w produkcie, ponieważ produkt ma być smaczny przede wszystkim dla dzieci.

Ponieważ myślę, że im mniej kolorowych obrazków, postaci z bajek, tym sok jest na $100 \%$ z owoców. Nie przyciąga wzroku postacią z bajki tak, jak zazwyczaj soczki dla dzieci nafaszerowane chemią.

Zazwyczaj bajkowe aplikacje na opakowaniach kojarzą mi się z dodawanymi ulepszaczami smaków.

Jednak także część rodziców, którzy wybrali sok z bohaterem marki, zaznaczało, że w pierwszej kolejności i tak sprawdziliby najpierw skład soku i dopiero po jego akceptacji zwróciliby uwagę na atrakcyjność opakowania.

Jeśli produkt ma dobry skład i kolorową ilustrację, to wezmę z kolorową ilustracją dla dziecka. Ale warunkiem koniecznym jest dobry skład. 
Bo miał jego ulubionego pingwina z bajki, ale w obu przypadkach przeczytałam najpierw jednak skład.

Zakładając, że zawartość jest zadowalająca, wybrałam miły dodatek dla dzieci.

\section{- Świadomość konsumencka}

Sok bez bohatera marki był także wybierany przez osoby, które uznały, że umieszczanie go na opakowaniu jest zabiegiem marketingowym obliczonym na skłonienie konsumenta do zakupu nie ze względu na jakość produktu, ale ze względu na atrakcyjne opakowanie. Część z tych osób miała poczucie, że wybierając sok bez bohatera marki, opiera się manipulacji producentów. Inne osoby wskazywały, że takie zabiegi marketingowe mają zapewne za zadanie kompensować słabszą jakość, dlatego wolały wybrać lepszy produkt w prostszym opakowaniu.

Bez dodatkowego marketingu w postaci rysunków mam wrażenie bardziej świadomego wyboru.

Nie jest za dużo grafik (prosto i czytelnie) i jest to czytelniejsze, pozostałe są marketingowo do naciągania, czego nie lubię.

Ponieważ brak barwnej etykiety utwierdza mnie w przekonaniu, że sok sam w sobie jest bardzo dobry i nie musi nadrabiać wyszukaną oprawą.

Bo nie ma za dużo dodatkowych rysunków, tzn. nie musi zastępować jakości marketingiem opakowania.

Również część rodziców sugerowała, że zabiegi marketingowe polegające na uatrakcyjnianiu opakowania elementami adresowanymi do dzieci świadczą często o nieuczciwości producentów, którzy starają się skłonić rodzica do wyboru swojego produktu za pośrednictwem dziecka.

Owoc bez żadnych dodatków na etykiecie. Nie lubię wymuszania zakupu na np. Kubusia Puchatka. To marketing i często tylko dlatego umieszcza się na np. butelce wspomnianego Kubusia, aby dziecko zapragnęło. A wiadomo - jak dziecko chce, to ciężko wytłumaczyć, że nie można, bo niezdrowe, bo za Kubusiem stoi 11 łyżeczek cukru itp. Ma być proste i czytelne, a nie kolorowe i z dodatkami, np. cukier.

- Ekonomia

Dla części osób wybierających sok bez bohatera marki istotne okazały się względy ekonomiczne. Uznano, że zazwyczaj produkty przeznaczone dla dzieci są droższe niż wersje tych samych produktów dla dorosłych. Zaznaczano przy tym, że wyższa cena nie zawsze idzie w parze z jakością. 
W przypadku bohaterów wielopokoleniowego oraz mainstreamowego zwracano także uwagę na fakt, że użycie tych postaci wymaga licencji, a to wiąże się z kosztami. Ostatecznie więc klient kupujący takie produktu niepotrzebnie przepłaca.

Takie obrazki kojarzą mi się z dodatkową opłatą, jeśli coś jest zrobione „specjalnie dla dziecka”, to zazwyczaj jest to trochę droższe.

Ponieważ inne prawdopodobnie byłyby droższe (licencjonowane wizerunki postaci z bajek).

Bo nie będę płacić więcej za bardziej kolorowe opakowanie tego samego produktu.

Podobnie jak w przypadku wyboru soku dla siebie, także wybierając sok dla dziecka, część osób, decydując się na wersję bez bohatera, stwierdziła, że kieruje się względami ekonomicznymi. Była to jednak grupa znacznie mniej liczna.

- Prostota

Wśród badanych wybierających sok bez bohatera marki były też osoby kierujące się estetyką opakowania. Uznały one, że etykieta bez dodatkowych - zbędnych, ich zdaniem - postaci jest najbardziej atrakcyjna wizualnie: elegancka i przyjazna.

Lubię proste opakowana, bez zbędnych ozdób graficznych.

Ładna, prosta i przyjazna grafika.

Wybrałem ten sok dlatego, że opakowanie jest proste, bez żadnych ulepszeń wizualnych.

Nie lubię zbędnej grafiki na opakowaniach. Cenię sobie minimalizm w tej kwestii.

W przypadku wyboru wersji z bohaterem marki osoby bezdzietne wskazały dwa motywy swoich wyborów: (1) sympatię do bohatera oraz (2) wspomnienie dzieciństwa. Natomiast rodzice wybierający jedną z wersji soku z motywem bajkowej postaci podzielali pierwszy motyw, ale drugiego już nie. Pierwszy motyw okazał się jednak znacznie bardziej złożony - rodzice deklarowali motyw wspólnej z dzieckiem sympatii do bohatera lub tylko sympatii dziecka do bohatera (mimo że wybór dotyczył soku dla siebie). Nowe motywy, które pojawiły się w uzasadnieniach wyboru soku dla dziecka, dotyczyły: (3) większej skuteczności perswazyjnej etykiety z bohaterem oraz (4) faktu, że część rodziców kierowała się pewnego rodzaju „egoizmem konsumenckim”, wybierając dla dzieci to samo co dla siebie. 
- Sympatia do bohatera marki

Wśród osób, które wskazały sok z bohaterem marki, większość wybrała Kłapouchego z bajki o Kubusiu Puchatku (bohater wielopokoleniowy) lub pingwina z bajki „Pingwiny z Madagaskaru” (bohater mainstreamowy). Obie te postaci są powiązane $z$ intensywnie promowanymi i obecnymi $\mathrm{w}$ mediach filmami. Nie są to więc tylko sympatyczne wizualnie zwierzątka, ale bohaterowie, którzy mają swój określony, znany widzom charakter oraz historię. Każda z tych postaci ma zatem określoną wartość emocjonalną i symboliczną i to właśnie zadecydowało o wyborze soku.

Ponieważ lubię Kubusia Puchatka.

Ponieważ lubię Kłapouchego, a wszystkie soki były 100\% organic.

Lubię serial „Pingwiny z Madagaskaru”.

Motyw sympatii do bohatera marki był jednak mniej jednorodny niż motywy wymienione powyżej. Oprócz tego, co było wspólne w wyborze tej wersji soku - czyli przewaga bohatera mainstreamowego i wielopokoleniowego nad bohaterem no-name zarówno w wyborach dla siebie, jak i dla dziecka pojawiły się także elementy różnicujące rodziców oraz osoby bezdzietne. Ci ostatni kierowali się wyłącznie swoją sympatią do postaci z bajki. Wśród rodziców można natomiast wyodrębnić grupę, która wybierając dla siebie sok z bohaterem marki, kierowała się jednak nie osobistymi preferencjami, ale preferencjami wspólnymi - swoimi i dziecka, a w uzasadnieniach często posługiwała się liczbą mnogą. Była też niewielka grupa rodziców, która opierała się wyłącznie na preferencjach swojego dziecka, a nie własnych, mimo że wybierała sok dla siebie.

Przemawia do mnie etykieta, to nasza ulubiona bajka - Kubuś Puchatek $\odot$.

Ponieważ lubimy Pingwiny z Madagaskaru. Ogólnie nalepka nie ma znaczenia, ważniejszy jest skład.

Lubimy z dziećmi bohatera bajki na obrazku.

Sugerowałam się motywem z bajki, którą interesuje się moje dziecko.

Na etykiecie jest postać z ulubionej bajki mojej córki.

Natomiast wybierając sok dla dziecka, duża część rodziców kierowała się wyłącznie sympatią dziecka do bohatera marki.

Moja córka lubi oglądać tę bajkę.

Wybrałam ten sok, ponieważ moje dziecko lubi „Pingwiny z Madagaskaru”. 
W przypadku osób, które wybrały sok z bohaterem no-name, sympatia do małpki opierała się na jej atrakcyjności wizualnej lub sympatii dziecka do tego gatunku zwierząt.

Ponieważ małpka wyglądała najsympatyczniej.

Etykieta z małpą jest według mnie najładniejsza. Pingwin był dla chłopaka, a kłapouch kojarzy mi się ze smutasem. Etykieta bez bohatera też była ładna, ale „pusta”.

Wybrałam opcję z małpką, ponieważ estetycznie podobała mi się najbardziej ze wszystkich.

Wybrałam, bo moje dziecko lubi małpki.

- Wspomnienie dzieciństwa - osoby bezdzietne

Część osób wybrała sok z bohaterem marki, ponieważ bajkowa postać wzbudziła w nich pozytywne skojarzenia z dzieciństwem.

Ponieważ jest to produkt, który ma kolorowe opakowanie i przedstawiona postać kojarzy mi się z dzieciństwem.

Ponieważ postać na nim przypomina dzieciństwo $)_{\text {. }}$

Zabawna naklejka z Kłapouchym przypomniała mi dzieciństwo, a z dzieciństwem kojarzy mi się wszystko, co najlepsze.

- Perswazyjna skuteczność etykiety - rodzice

Duża grupa rodziców zwracała uwagę, że obecność na etykiecie animowanej postaci, zwłaszcza lubianej przez dziecko, znacznie bardziej zachęci je do wypicia soku. W związku z tym, jeśli uznali, że sok jest zdrowy, decydowali się na taką wersję opakowania, która najskuteczniej zachęci dziecko do wypicia go.

Bo mój syn bardzo lubi Kubusia Puchatka i Osiołka, a nie lubi próbować nowych rzeczy. A soku z ulubionej bajki na pewno by spróbował.

Ponieważ moje dzieci lubią Pingwiny z Madagaskaru i często, widząc bohatera bajki, chętniej ten produkt wybierają. Dla młodszej kupiłabym także sok z Kłapouchym.

Z pewnością dużo chętniej wypije ten sok, opatrzony etykietą z jego ulubionym bohaterem bajki w tle.

Dzieci lubią obrazki bohaterów z bajek, myślę że może to być zachętą, wiem po moim dziecku, że jest $(-)$.

- Egoizm konsumencki - rodzice

Niewielka część rodziców wybrała dla dziecka sok, kierując się wyłącznie własnymi preferencjami. 
Niczym się te soki nie różnią. Dlatego wybrałam dla dziecka taki sam, jak dla mnie.

Bo wybrałam taki sam dla siebie.

Wybierałam pod siebie. Sobie wzięłabym taki sam.

- Inne motywy - niewłaściwe adresowanie produktu

W grupie osób dorosłych, które wybrały dla siebie sok bez bohatera marki, pojawił się jeszcze jeden motyw: niewłaściwe adresowanie produktu. Duża część osób wybrała po prostu jedyną „dorosłą” wersję, która nie miała żadnych „dziecinnych” elementów. Wskazywano, że obecność bohatera marki sugeruje, iż produkt przeznaczony jest dla dzieci, a opakowanie - infantylne.

Wydaje mi się, że jest najbardziej odpowiedni dla osób dorosłych, bez żadnych postaci z bajek, które kojarzą się z dzieciństwem.

Ponieważ pozostałe są kierowane raczej do dzieci.

- Brak motywu - wybór losowy

Zarówno w grupie rodziców, jak i osób bezdzietnych znalazła się dość mała grupa osób, która zadeklarowała, że właściwie nie wybrała żadnego soku, tylko wskazała jeden z nich losowo. Niektóre z nich sugerowały, że zdały się na przypadek, ponieważ w ogóle nie kupują soków i piją tylko wodę lub soki robione samodzielnie w domu. Inne stwierdziły, że ich zdaniem etykieta i tak nie ma znaczenia lub że ważniejszy od etykiety jest skład produktu.

Przeważnie biorę „pierwszy lepszy”.

Wybrałam losowo.

Szczerze, nie mam pojęcia, nie zwracam uwagi na taki drobny szczegół.

Podsumowanie motywów, którymi kierowali się badani, dokonując wyboru soku dla siebie lub/i dla dziecka, obrazuje tabela 3, w której pominięto wybór losowy oraz kategorię „niewłaściwe adresowanie produktu”. W tym drugim przypadku założenie osoby badanej, że produkt adresowany jest do innej grupy odbiorców, nie dawał podstaw do oceny jej stosunku wobec obecności bohatera marki. Zestawienie motywów wyboru soku w tabeli pozwoliło także podzielić je na dwie kategorie oparte na rodzaju argumentów przytaczanych przez osoby badane - racjonalnych bądź emocjonalnych. Z kategorii argumentów racjonalnych najczęściej wskazywano zdrowie, natomiast najpopularniejszym argumentem emocjonalnym była sympatia dziecka do bohatera. 


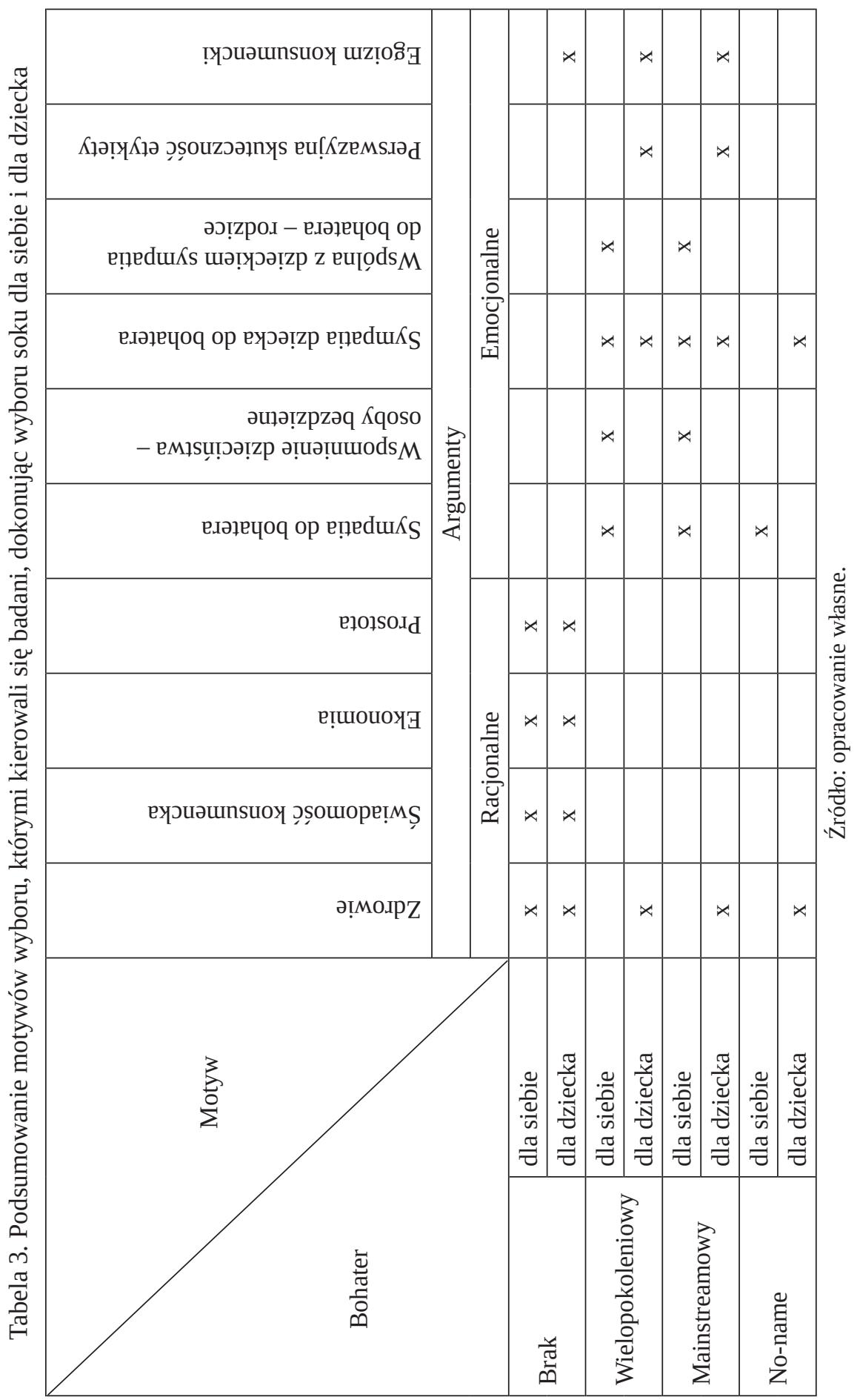




\section{Dyskusja wyników}

Przeprowadzone badanie miało na celu zweryfikowanie wpływu bohatera marki umieszczonego na opakowaniu produktu na decyzje zakupowe dorosłych klientów. W tym wypadku produktem był sok owocowy, a klientem osoby bezdzietne oraz rodzice dzieci w okresie wczesnego i średniego dzieciństwa. Analiza ilościowa wykazała, że najczęściej wybieraną opcją soku dla siebie - zarówno przez rodziców, jak i osoby bezdzietne - była wersja bez bohatera marki. W przypadku wyboru soku dla dziecka okazało się, że rodzice z podobną częstotliwością wybierali wersje soku bez bohatera marki, jak i z bohaterem wielopokoleniowym oraz mainstreamowym. Z kolei wśród wersji z bohaterem marki rodzice najrzadziej wybierali dla swoich dzieci sok z bohaterem no-name.

Jakościowa analiza uzasadnień dokonanych wyborów pozwoliła lepiej zrozumieć proces podejmowania decyzji i motywy, jakimi kierowali się uczestnicy badania. Po pierwsze, niezależnie od tego, czy badani wybierali sok dla siebie czy dla dziecka - osoby wybierające wersję bez bohatera marki w największym stopniu odwoływały się do argumentacji racjonalnej (Rudnicki, 2012). Najczęściej przywoływanymi przez nich motywami były: zdrowie, świadomość konsumencka i ekonomia (zob. poniżej). Z kolei osoby decydujące się na sok z bohaterem marki kierowały się głównie argumentami emocjonalnymi. Najważniejszym z nich była sympatia do bohatera, która miała różne oblicza - mogła być sympatią rodzica, dziecka lub obojga do wybranej postaci, zwykle wynikającą ze wcześniejszej więzi z danym bohaterem. W przypadku osób bezdzietnych ważnym motywem była także nostalgia, gdy bohater (najczęściej wielopokoleniowy) przywoływał wspomnienia z dzieciństwa (funkcja emocjonalno-motywacyjna pamięci autobiograficznej, Maruszewski, 2005; por. rynek przyszłości, McNeal, 1998). Ponieważ większość wskazań na wersję bez bohatera marki pojawiła się w sytuacji wyboru soku dla siebie, a w przypadku wyboru soku dla dziecka dominowały wersje z bohaterem marki, wyniki badania są zgodne z założeniem, że marketing skierowany do dzieci musi być silnie nacechowany emocjonalnie, aby je zainteresować i przyciągnąć ich uwagę. Z kolei ten skierowany do rodziców musi być raczej racjonalny, aby ich przekonać i nakłonić do zakupu (Całka, 2006). Uzyskany wynik wskazuje również, że ten sam produkt może być różnie postrzegany w zależności od adresata (Jasielska i Kaczmarek, 2010; Jasielska i Maksymiuk, 2017). Jeśli odwołamy się do klasyfikacji reklam 
znanej jako macierz FCB (Kall, 1998), reklamy soków jako jednego z produktów żywnościowych powinny się znaleźć w kategorii reklam tworzących nawyk. Zaangażowanie w zakup tego typu produktów jest raczej niewielkie, a decyzja opiera się na argumentach poznawczych, chociaż nie wymaga od klienta każdorazowej analizy sytuacji, oceny konkurencji itp., ponieważ są one kupowane rutynowo. Na podstawie wcześniejszych doświadczeń klient tworzy bowiem zestaw odpowiadających mu marek i korzysta z niego, dokonując codziennych zakupów. W sytuacji gdy badani mieli wybrać sok nieznanej marki, szukali wskazówek, które pomogą im ocenić produkt, i wygląd etykiety był jedną z nich. Wybierając sok dla siebie, na etykiecie szukali argumentów poznawczych, które pozwolą im zdecydować, czy produkt warto wypróbować i włączyć do stałego repertuaru wybieranych marek. Jednak decydując się na sok dla swojego dziecka, traktowali napój raczej jak produkt, który musi trafić w jego indywidualny gust. Produkty takie w siatce FCB klasyfikowane są jako te wymagające reklamy dającej satysfakcję. Oznacza to, że celem jest przyciągnięcie odbiorcy, a następnie stworzenie wyróżniającego się wizerunku marki. Na wizerunek marki składają się zaś także elementy emocjonalne, i to one najsilniej oddziałują na dzieci. W przypadku prezentowanego badania obecny na etykiecie bohater marki był jednym z elementów tworzących wizerunek marki.

Warto zatem przyjrzeć się skojarzeniom, jakie niosła za sobą obecność bohatera marki lub jego brak, i konsekwencjom tych skojarzeń dla decyzji o wyborze soku. Okazało się, że jednym z najważniejszych motywów wyboru soku zarówno dla siebie, jak i dla dziecka było zdrowie. Z tego powodu badani decydowali się na soki z etykietami, które w ich opinii dawały lepszą „gwarancję”, że kupują produkt zdrowy, ekologiczny, pozbawiony chemicznych dodatków. Należy także dodać, że wiele osób zaznaczało, iż etykieta byłaby elementem decydującym o zakupie tylko wówczas, gdyby wcześniej osoba zaakceptowała skład soku. Zaskakujący okazał się fakt, że w opinii wielu osób (w tym także rodziców) elementy opakowania sugerujące, że produkt przeznaczony jest dla dzieci - takie właśnie jak bohater marki podważają zaufanie do jakości produktu. Osoby te wyjaśniały, że soki (i inne produkty spożywcze) przeznaczone dla najmłodszych zawierają zbyt dużą ilość cukru, konserwantów czy substancji „ulepszających” smak. Można zatem wnioskować, że produkty spożywcze adresowane do dzieci wcale nie kojarzą się osobom dorosłym z wysokimi standardami jakości, ale wręcz przeciwnie. Warto jednak dodać, że nie były to produkty kierowane do najmłodszych dzieci (do pierwszego roku życia), lecz nieco starszych. Wyniki badania wskazują, że etykietą, która w największym stopniu przekonywała 
o tym, że sok jest zdrowy, była ta bez bohatera marki. Okazało się, że jego brak sugerował adresowanie produktu do osób dorosłych i dlatego z jednej strony był przez badanych najczęściej wybierany dla siebie, a z drugiej strony rodzice często wybierali go także dla dzieci, uznając, że nie zawiera niepożądanych dodatków smakowych (wybierali więc dla dziecka to samo co dla siebie, kierując się tą samą argumentacją). Wynik ten pozostaje w opozycji do przesłanek świadczących o powszechności zjawiska infantylizacji kulturowej. Ulegający mu dorośli powinni być zainteresowani produktami opatrzonymi dziecięcymi Brand Hero, skoro także w produkcji reklamowej dla dorosłych pojawiają się „,bohaterowie jak z bajki” o jednoznacznych rolach, np. dobry-zły, pełniący ,archetypowe” funkcje: wroga, ofiary i wybawiciela (por. Ryłko-Kurpiewska, 1997).

Brak bohatera marki był także dla części osób wskazówką, że produkt jest tańszy, ponieważ nie trzeba płacić za licencjonowane postaci, oraz że promocja produktu opiera się na jego jakości, a nie „,chwytach” marketingowych. Na podstawie uzasadnień pojawiających się przy wyborze wersji soku z etykietą bez bohatera możemy zatem wysnuć wniosek będący w sprzeczności z założeniami dotyczącymi bohatera marki. Brand Hero ma za zadanie wzbudzać sympatię i przekazywać informacje na temat marki (Dołhasz, 2013; Styś, 2006b). Jednak przeprowadzone badanie wskazuje, że wykorzystanie bohatera marki w kategorii produktów dla dzieci może wzbudzać opór konsumentów przed manipulacją ze strony producenta, obniżać zaufanie do marki i przede wszystkim komunikować nie zalety (zdrowy, bo adresowany do dzieci), ale wady produktu (zawierający niezdrowe dodatki, bo adresowany do dzieci). Jest to zapewne nie tyle problem postrzegania konkretnego rodzaju bohatera marki (w badaniu wykorzystano trzy różne kategorie bohaterów) czy w ogóle wykorzystania jakiegokolwiek bohatera jako narzędzia komunikacji, ile raczej odzwierciedlenie postawy konsumentów wobec kategorii produktów spożywczych dla dzieci i ich wiedzy potocznej na ten temat. Na podstawie badania można uznać, że wiele osób, także rodziców, nisko ocenia jakość takich produktów. Zakładają oni także, że atrakcyjne elementy opakowania stanowią substytut jakości lub mają za zadanie odwrócić od niej uwagę, są więc przykładem nieuczciwości producentów i braku dbałości o klienta. Etykiety bez postaci postrzegane były zatem jako bardziej „uczciwe”, koncentrujące uwagę na informacjach o produkcie, a dla dużej grupy osób ich prosta forma była także bardziej elegancka.

Te negatywne poznawcze skojarzenia z bohaterem marki były jednak równoważone przez pozytywne skojarzenia emocjonalne, kluczowe dla osób wybierających sok z Brand Hero. Duża część z nich deklarowała 
sympatię do wybranej postaci. Szczególnie bohaterzy wielopokoleniowy i mainstreamowy cieszyli się popularnością zarówno wśród osób bezdzietnych, jak i rodziców (w obu decyzjach - wyboru dla dziecka i wyboru dla siebie). W tym przypadku badanie potwierdziło istnienie pozytywnych emocji i lojalności wobec postaci przenoszonych na markę (por. Dołhasz, 2013). Także jednak bohater no-name potrafił wzbudzić sympatię wynikającą albo z graficznej atrakcyjności postaci, albo z przeniesienia sympatii dziecka do określonej grupy obiektów (np. małpek) na konkretną postać będącą jej przedstawicielem. Wypowiedzi rodziców, którzy wybrali sok z bohaterem marki atrakcyjnym zarówno dla nich, jak i ich dziecka, wskazują na celowość tworzenia reklam adresowanych jednocześnie do dzieci i rodziców. W ramach rynku wpływu już od pewnego czasu identyfikuje się bowiem konsumenta „o czterech oczach i czterech nogach” (four-eyed, four-legged consumer), którego siła nabywcza - zdaniem specjalistów opiera się na harmonijnej koegzystencji matki i dziecka (Schor, 2005, s. 62). W niektórych sytuacjach rodzice wybierający sok z bohaterem marki kierowali się jednak argumentami racjonalnymi (ze swojej perspektywy), wykorzystując emocjonalne z perspektywy dziecka elementy marki. Osoby te uznały, że łatwiej będzie im nakłonić dziecko do wypicia zdrowego soku, gdy na etykiecie będzie jego ulubiona postać (van Buuren, 2017). Dodać należy, że chociaż pewna część rodziców uważała, iż etykieta bez bohatera marki sugeruje zdrowszy produkt, to była też duża grupa rodziców, która wybierając sok z bohaterem marki, nie pomijała wcale aspektu zdrowia. Osoby te po prostu zakładały odgórnie, że sok jest zdrowy, na podstawie skojarzeń z tą kategorią produktu i wybierały wersję atrakcyjniejszą dla dziecka albo zaznaczały, że najpierw sprawdziłyby skład soku i gdyby był satysfakcjonujący, to wówczas decydującym elementem byłaby etykieta i obecny na niej bohater.

W grupie uczestników badania znaczną część stanowiły kobiety. Sprawia to, że badanie jest trafne ekologicznie, ponieważ 8 na 10 decyzji konsumenckich podejmują właśnie kobiety (Kozielski, 2012), ponadto to matki w przewadze kupują produkty dla dzieci (Kasser i Kanner, 2004; Szlendak, 2005). Na korzyść badania może też świadczyć fakt, że swoją konstrukcją przypominało zakupy w internecie, które w coraz większym zakresie zyskują na popularności szczególnie w grupie młodych matek (Badanie „Matka 2.0. Potencjał marketingowy matek w polskich mediach społecznościowych”, 2012). Słabość badania polega na tym, że pozostajemy w sferze preferencji i deklaracji, a nie rzeczywistych wyborów konsumenckich. 
Podsumowując, można powiedzieć, że obecność bohatera marki na produktach adresowanych do dzieci, z jednej strony, ułatwia rodzicom wybór produktu, ale nie zawsze konotuje takie jego cechy, na jakich może zależeć producentowi. Oznacza to dla marketerów konieczność przeprowadzenia analiz nie tylko na poziomie wykorzystania konkretnej postaci jako bohatera, ale w ogóle bohatera jako narzędzia komunikacji. Z punktu widzenia psychologów bardzo ważne i pozytywne są wyniki świadczące o tym, że duża grupa rodziców podejmuje decyzje o zakupie produktów dla dzieci w sposób świadomy, opierając się nie tylko na wiedzy z obszaru zdrowia czy zdrowego żywienia, ale także z obszaru działań marketingowych. Edukacja konsumencka jest bowiem bardzo ważnym elementem przygotowania dzieci do życia w społeczeństwie konsumpcyjnym, a wyedukowani w tym zakresie rodzice będą na pewno mieli znaczący i pozytywny wpływ na kształtowanie świadomości konsumenckiej swoich dzieci (Zawadzka, Skwira i Solecka, 2017; por. edukacja ekonomiczna dzieci, Maison, Furman, Sekścińska, Trzcińska i Poraj-Weder, 2018).

\section{Literatura}

Altkorn, J., Kramer, T. (1998). Leksykon marketingu. Warszawa: Polskie Wydawnictwo Ekonomiczne.

Barber, B. R. (2008). Skonsumowani. Jak rynek psuje dzieci, infantylizuje dorosłych i połyka obywateli, przeł. H. Jankowska. Warszawa: Warszawskie Wydawnictwo Literackie Muza.

Bogunia-Borowska, M. (2006). Infantylizacja kulturowa. Adolescencja dzieci oraz infantylizacja dorosłych. W: M. Bogunia-Borowska (red.), Dziecko w świecie mediów i konsumpcji (ss. 13-44). Kraków: Wydawnictwo Uniwersytetu Jagiellońskiego.

Brzezińska, A. I. (2005). Jak przebiega rozwój człowieka? W: A. I. Brzezińska (red.), Psychologiczne portrety człowieka (ss. 21-39). Gdańsk: Gdańskie Wydawnictwo Psychologiczne.

Buuren, van, I. (2017). Bajka jako centrum sprzedażowe. W: A. M. Zawadzka, M. Niesiobędzka (red.), Tajemnice reklamy. O tym, jak reklama wpływa na dzieci i młodzież (ss. 63-76). Warszawa: Liberi Libri.

Całka, D. (2006). Jak zbudować wizerunek silnej marki dziecięcej, Marketing przy kawie, 118, http://www.marketing-news.pl/theme.php?art=360, dostęp: 30.12.2008.

Chodorowska, M. (2013). Wpływ obecności maskotki na skojarzenia zwiqzzane z produktem w reklamach nisko angażujq̨cych, niepublikowana praca magisterska. Warszawa: SWPS.

Comstock, G., Scharrer, E. (2007). Media and the American Child. Oxford: Elsevier Science Ltd.

Dołhasz, M. (2013). Nowe sposoby oddziaływania na nabywców w komunikacji marketingowej przedsiębiorstw - Brand Hero. Zeszyty Naukowe Uniwersytetu Szczecińskiego. Problemy Zarzq̨dzania, Finansów i Marketingu, 777, 311-324. 
Domska, A. (2016). Wpływ bohatera marki (Brand Hero) na decyzje zakupowe dorosłych konsumentów, niepublikowana praca magisterska. Poznań: Instytut Psychologii UAM.

Duhigg, C. (2013). Siła nawyku, przeł. M. Guzowska. Warszawa: Wydawnictwo Naukowe PWN.

Dykalska-Bieck, D. (2017). Budujemy społeczność - konsument od kołyski. W: A. M. Zawadzka, M. Niesiobędzka (red.), Tajemnice reklamy. O tym, jak reklama wpływa na dzieci i młodzież (ss. 63-76). Warszawa: Liberi Libri.

Frąckiewicz, S. (2007). Popmarketing - reklamy z grzechem, Marketing przy kawie, 163, http://www.marketing-news.pl/theme.php?art=538, dostęp: 30.12.2008.

GfK (2015). Raport „Junior Shopper 2015”, http://www.gfk.com/pl/aktualnosci/pressrelease/miesieczna-sila-nabywcza-dzieci-w-polsce-wynosi-niemal-348-mln-zl/, dostęp: 20.08.2016.

Godlewska, M., Gorbaniuk, O. (2007). Cechy strukturalne przekazu reklamowego a jego odbiór przez dzieci. W: P. Francuz, W. Otrębski (red.), Studia z psychologii w KUL, t. 14 (ss. 153-170). Lublin: Wydawnictwo Katolickiego Uniwersytetu Lubelskiego.

Gunter, B., Furnham, A. (1998). Children as Consumers: A Psychological Analysis of the Young People's Market. London-New York: Routledge.

Halawa, M. (2006). Komercjalizacja dzieciństwa. Kosztorysowanie rodzicielstwa. W: M. Bogunia-Borowska (red.), Dziecko w świecie mediów i konsumpcji (ss. 45-55). Kraków: Wydawnictwo Uniwersytetu Jagiellońskiego.

IRCenter (2012). Raport „Matka 2.0. Potencjał marketingowy matek w polskich mediach społecznościowych", https://marketingprzykawie.pl/artykuly/matka-2-0-potencjalmarketingowy-matek-w-polskich-mediach-spolecznosciowych/, dostęp: 13.12.2018.

Iwasiński, Ł. (2015). Społeczeństwo konsumpcyjne w ujęciu Zygmunta Baumana. Kultura i Społeczeństwo, 4, 3-22.

Jasielska, A., Kaczmarek, L. (2010). Decyzje konsumenckie rodziców na rynku wpływowym na przykładzie zabawek. Marketing i Rynek, 4, 38-44.

Jasielska, A., Maksymiuk, R. A. (2010a). Wpływ infantylizacji kultury na zmiany w społeczeństwie konsumpcyjnym. Kultura i Społeczeństwo, 2, 5-20.

Jasielska, A., Maksymiuk R. A. (2010b). Dorośli reklamujq, dzieci kupujq. Kindermarketing i psychologia. Warszawa: Wydawnictwo Naukowe Scholar.

Jasielska, A., Maksymiuk R. A. (2011). Skomercjalizowane rodzicielstwo - nowy aspekt wczesnej dorosłości. Psychologia Rozwojowa, 16 (3), 33-49.

Jasielska, A., Maksymiuk, R. (2017). Skuteczność działań marketingowych wykorzystujących seksualizację wizerunku dziewczynek w promowaniu produktów dla dzieci. Dziecko Krzywdzone, 16 (4), 119-137.

Jędrkiewicz, T. (2006). Licencja na własnego bohatera, Marketing przy kawie, 121, http:// www.marketing-news.pl/theme.php?art=375, dostęp: 30.12.2008.

Kahneman, D. (2012). Pułapki myślenia: o myśleniu szybkim i wolnym, przeł. P. Szymczak. Poznań: Media Rodzina.

Kall, J. (1998). Reklama. Warszawa: Polskie Wydawnictwo Ekonomiczne.

Kasser, T., Kanner, A. D. (red.) (2004). Psychology and Consumer Culture: The Struggle for a Good Life in a Materialistic World. Washington: APA.

Kołodziejczyk, A. (2012). Trzy podejścia do wyjaśniania natury procesu socjalizacji konsumenckiej. Psychologia Społeczna, 3, 272-280. 
Kozielski, R. (2012). Czego pragną kobiety? Konferencja „Customer Empowerment, czyli klient ma głos”. Organizator portal Prekursorki.pl, Warszawa, 6 listopada 2012.

Lewandowski, G. (2007). Fenomen alfamamy. Marketing przy kawie, http://www.marketingnews.pl/article.php?art=1137, dostęp: 28.03.2010.

Lindstrom, M. (2005). Dziecko reklamy, przeł. A. M. Kawalec. Warszawa: Wydawnictwo „Świat Książki”.

Linn, S. (2004). Consuming Kids. The Hostile Takeover of Childhood. New York-London: The New Press.

Maison, D. (1998). Techniki oddziaływania i typy przekazu stosowane w reklamie. W: Konferencje i Seminaria. Dziecko jako konsument - zagrożenia i ochrona. Biuletyn Biura Studiów i Ekspertyz Kancelarii Sejmu.

Maison, D., Furman, A., Sekścińska, K., Trzcińska, A., Poraj-Weder, M. (2018). Edukacja i socjalizacja ekonomiczna dzieci - rodzice jako źródło wiedzy, wzorców zachowań, wartości i emocji wobec finansów. Marketing i Rynek, 5, 15-27.

Mark, M., Pearson, C. S. (2001). The hero and the outlaw. Building Extrordinary Brands Through the Power of Archetypes. NewYork: McGraw-Hill.

Maruszewski, T. (2005). Pamięć autobiograficzna. Gdańsk: Gdańskie Wydawnictwo Psychologiczne.

McNeal, J. U. (1998). Kids’ markets. American Demographics, 20 (4), 36-42.

Moskowitz, L. (2000), What kind of mother are you? Marketing mavens dissect moms for eager advertisers,http://www.salon.com/mwt/feature/2000/02/28/marketing/index. html, dostęp: 15.03.2010.

Müller, J. (2016). Jak sobie radzą polscy brand heroes? Przegląd 20-lecia. Marketing przy kawie, 594, http://www.marketing-news.pl/theme.php?art=2123, dostęp: 16.07.2018.

Oczachowska, A. (2010). Wpływ dzieci na zachowania nabywcze ich rodziców. Zeszyty Naukowe Uniwersytetu Szczecińskiego. Ekonomiczne Problemy Usług, 594, 239-248.

Pallach, R. (2013). Jak dotrzeć do generacji Z, czyli marketing wśród tubylców ery cyfrowej. Marketing przy kawie, 433, http://www.marketing-news.pl/theme.php?art=1624, dostęp: 22.07.2018.

Piaget, J. (2006). Jak sobie dziecko wyobraża świat, przeł. M. Gawlik. Warszawa: Wydawnictwo Naukowe PWN.

Podlaszewska, K., Szlendak, T. (2003). Dlaczego dzieci lubią to, co lubią? O psycho-ewolucyjnych argumentach na rzecz hipotezy o wrodzonym zamiłowaniu do kiczu. Czasopismo Psychologiczne, 9, 79-88.

Postman, N. (1994). The Disappearance of Childhood. New York: Vintage Books.

Riegel, M., Wierzba, M., Wypych, M., Żurawski, Ł., Jednoróg, K., Grabowska, A., Marchewka, A. (2015). Nencki Affective Word List (NAWL): the cultural adaptation of the Berlin Affective Word List - Reloaded (BAWL-R). Behavior Research Methods, 47 (4), 1222-1236.

Rotkiewicz, M. (1995). Moralność reklamowa. Rzeczpospolita, 98, 6.

Rudnicki, L. (2012). Zachowania konsumentów na rynku. Warszawa: Polskie Wydawnictwo Ekonomiczne.

Rudnicki, S., Szwed, A. (2014). Przepis na brand hero - podpowiedzi semiotyków. Marketing przy kawie, 482, http://www.marketing-news.pl/theme.php?art=1826, dostęp: 13.06.2018. 
Ryłko-Kurpiewska, A. (1997). Bohater z bajki. Aida Media, 12, 6-11.

Schor, J. (2005). Born to buy: the commercialized child and the new consumer culture. New York-London-Toronto-Sydney: Scribner.

Sewera, I. (2013). Gwiazdka dla matki z pokolenia Y. Marketing przy kawie, https:// marketingprzykawie.pl/artykuly/gwiazdka-dla-matki-z-pokolenia-y/, dostęp: 16.07.2018.

Solomon, M. R. (2004). Consumer Behavior. Buying, Having, and Being. Upper Saddle River, NJ: Pearson Education.

Stasiuk, K., Maison, D. (2014). Psychologia konsumenta. Warszawa: Wydawnictwo Naukowe PWN.

Styś, M. (2006a). Konsument bez metryki. Marketing w Praktyce, 6, 10-12.

Styś, M. (2006b). Czy marce potrzebny bohater? Marketing w Praktyce, 4, 49-51.

Sutterby, J. A. (2009). Toys and child development. W: R. Carlisle (red.), Encyclopedia of play in today's society (ss. 725-729). New Brunswick: A SAGE Reference Publication.

Szlendak, T. (2005). Leniwe maskotki, rekiny na smyczy. W co kultura konsumpcyjna przemieniła mężczyzn i kobiety. Warszawa: Jacek Santorski \& Co Agencja Wydawnicza.

Szol, E. (1979). Identyfikacja z bohaterem jako psychologiczny mechanizm odbioru filmu. W: M. Tyszkowa (red.), Sztuka dla dzieci szkolnych. Teoria - Recepcja - Oddziaływanie. Warszawa-Poznań: PWN.

Szubielska, M., Dziopa, K. (2017). Media a rozwój pojęciowy: badanie nazywania zwierzęcych bohaterów filmów animowanych przez dzieci. Psychologia Społeczna, 12, 304-318.

Szymańska, K. (2008). Analiza i ocena reklam dla kobiet w okresie ciqży i wczesnego macierzyństwa, niepublikowana praca magisterska. Łódź: Katedra Marketingu Wydziału Zarządzania Uniwersytetu Łódzkiego.

Trempała, J. (2002). Rozwój poznawczy. W: B. Harwas-Napierała, J. Trempała (red.), Psychologia rozwoju człowieka. Rozwój funkcji psychicznych (ss. 13-44). Warszawa: Wydawnictwo Naukowe PWN.

Wilcox, B. L., Kunkel, D., Cantor, J., Dorwrick, P., Linn, S., Palmer, E. (2004). Report of the APA task force on advertising and children, https://www.apa.org/pi/families/resources/ advertising-children.pdf, dostęp:16.07.2018.

Witek-Hajduk, M. K. (2010). Cykl życia marki na rynku. Zeszyty Naukowe Szkoła Główna Handlowa. Kolegium Gospodarki Światowej, 27, 181-201.

Zajonc, R. (1985). Uczucie a myślenie: nie trzeba się domyślać, żeby wiedzieć, co się woli. Przegląd Psychologiczny, 28, 27-72.

Zawadzka, A. M., Niesiobędzka, M., Godlewska-Werner, D. (red.) (2014). Kultura konsumpcji - wartości cele, dobrostan. Psychologiczne aspekty zjawiska. Warszawa: Liberi Libri.

Zawadzka, A. M., Skwira, M., Solecka, S. (2017). Równowaga w świecie materializmu i reklamy? Edukacja konsumencka i edukacja społeczna dzieci i młodzieży. W: A. M. Zawadzka, M. Niesiobędzka (red.), Tajemnice reklamy. O tym, jak reklama wpływa na dzieci i młodzież (ss. 117-128). Warszawa: Liberi Libri. 